Urologia

Internationalis

\section{Review}

Urol Int 2020;104:2-9

DOI: $10.1159 / 000501109$
Received: May 13, 2019

Accepted: May 18, 2019

Published online: June 24, 2019
Friedrich H. Molla, b

Jörg-Michael Moll-Keyn ${ }^{b}$

a Institute for the History, Philosophy and Ethics of Medicine, Heinrich-Heine-University, Duesseldorf, Germany; ${ }^{b}$ Custos, Museum of the DGU, Berlin, Germany

\title{
Urology on Display: Museum, Library and Archives of the DGU Duesseldorf-Berlin
}

\author{
Keywords \\ History of urology · Museums · Collections - Culture of \\ remembrance $\cdot$ Heritage $\cdot$ History of science
}

\begin{abstract}
Within a modern changing academic society, it has become necessary and important for scientific collections and museums as decentralized infrastructures for research, teaching, and education, to define and redefine their missions, their goals, their functions, and their strategies to reflect the expectations of a changing society and the academic world, especially museums of scientific associations as possessing critical resources. For example, the dues of the members are on task for education and promotion of the specials values of these communities under aspects of historical marketing and corporate museums which promote heritage.
\end{abstract}

(c) 2019 S. Karger AG, Basel

\section{Introduction}

Collections of medical associations and universities [1, 2] are among the most intriguing places of existence [3]. They are still irreplaceable places of "cultural remembrance" (Jan Assman) [4]. The collections of the Deutsche Gesellschaft für Urologie e. V. (DGU) [5] are the only few of its kind besides those of the American Urological As-

$\begin{aligned} & \text { karger@karger.com } \\ & \text { www.karger.com/uin }\end{aligned}$
Karger

sociation in Baltimore/Linthicum at the William P. Didusch Center for Urologic history $[6,7]$ or the newly (2019) established collections of the EAU at the headquarter in Arnhem [8]. The institution belongs to the fascinating collections from across the globe demonstrating the diversity of the specialty of urology. The museum, library, and archives are an important storage space for all kinds of objects, artifacts, and resources related to urology in general but also a signpost for excellence of the medical specialty over the times and the institution reveals how history has an impact on everyone alive [9].

This article explores the collections within the museum, library, and archives of the DGU in order to understand how academic medical societies handle their past under aspects of the culture of remembrance [10] and under aspects of historical marketing. First, we look on the development of the collections on aspects of the constitution of the specialty. Later on, we focus on the tasks, aims, and visions.

Interestingly, a detailed research concerning the development of collections of universities or medical associations is just lacking and the impact they had within the formation process of the specialties [11]. Since the 1980th within museology and cultural studies, the inter-

Priv. Doz. Dr. med. Friedrich H. Moll, MA, FEBU

Curator, Museum zur Geschichte der Urologie, Deutsche Gesellschaft für Urologie e. V. Düsseldorf-Berlin, Institut für Geschichte, Theorie und Ethik der Medizin, HeinrichHeine-Universität Duesseldorf, c/o Urologische Klinik, Kliniken der Stadt Köln gGmbH, Neufelder Strasse 32, DE-51067 Köln (Germany)

E-Mail friedrich.moll@uni-koeln.de

Jörg-Michael Moll-Keyn

Custos, Museum zur Geschichte der Urologie, Deutsche Gesellschaft für Urologie e. V. Museum zur Geschichte der Urologie Duesseldorf- Berlin Martin-Buber-Strasse 10, DE-14136 Berlin (Germany)

E-Mail museum@dgu.de or museum-dgu@web.de 
Table 1. Establishment of urological societies (sample)

\begin{tabular}{lll}
\hline USA & 1884 & AAGUS \\
France & 1896 & AFU \\
Belgium & 1901 & SBU \\
USA & 1902 & AUA \\
Germany & 1907 & DGU \\
Russia & 1907 & Urologicheskoy assotsiatsii (урологической ассоциации) \\
International & 1907 & AIU/SIU \\
Netherlands & 1908 & Nederlandse vereneging voor urologie \\
Italy & 1908 & SIU \\
Spain & 1911 & Asociatión espaniola de urologia \\
Japan & 1912 & Japanese urological association \\
Austria & 1919 & WUG, 1935/1946 ÖGU \\
\hline \multicolumn{2}{c}{ AAGUS, American Association Genito Urinary Surgeons; AFU, Association Francaise d'Urologie; SBU, Société Belge d'Urologie; } \\
AUA, American Urological Association; DGU, Deutsche Gesellschaft für Urologie; AIU/SIU, Association Internationale d'Urologie; \\
SIU, Socièta Italiana di Urologia; WUG, Wiener Urologische Gesellschaft; ÖGU, Österreichische Gesellschaft für Urologie. \\
\hline
\end{tabular}

Table 2. Museums of medical associations (the list is not exhaustive)

Hunterian Museum, Royal College of Surgeons, London

International Museum of Surgical Science, International College of Surgeons, Chicago

Muetter Museum, College of Physicians, Philadelphia

Lepramuseum Münster Kinderhaus, Deutsche Gesellschaft für Leprakunde e. V. Münster

British Optical Association Museum, British Optical Association, London

The American Academy of Ophthalmology Foundation Museum, San Francisco

William Wood Archives and Museum, American Association of Anesthesiology, Chicago

W.P. Didusch Center for Urologic History, American Urological Association, Linthicum

Museum, Bibliothek und Archiv zur Geschichte der Urologie, Deutsche Gesellschaft für Urologie e. V., Düsseldorf-Berlin

Museum of Urology, Arnhem, European Association of Urology, Arnhem

est within this research field grows up rapidly [12]. In 2011, the German Science Council focusses on such collections as research infrastructures [13] (Tables 1,2) and important places for teaching and education.

\section{A Short History of the DGU Under Aspects of the Specialization Process in Medicine}

To understand the development of a museum of a scientific society, some remarks on the history of the association from the point of view of the development of scientific associations in Europe in the 19th century are necessary. The "Assembly of German Naturalists and Physicians" was the crystallization point of several scientific associations in Germany since the middle of the 19th century not only within Germany or within the Germanspeaking countries. Just since the 1830th, we can trace back subdivisions and specializations in medicine during these meetings of this distinguished assembly: Sections of practical medicine, later sections for internal medicine, surgery, or obstetrics. Within these sections, we can easily trace topics related to the field of urology as urolithiasis, the therapy of stones (e.g., lithotripsy), urethral strictures, or STD.

Another important option for physicians to meet within specializing medicine in the middle of the 19th century were the "International medical congresses," which were established after the first World Exhibition in 1851 and gained favor rapidly. Here urologic topics were presented mainly within the sections of surgery or internal medicine, some other within the section of dermatology. Within the reports of the assembly, we find well-known German names as one of the co -founders of the old DGU Leopold Casper (1859-1959), which underlines the importance of the international meetings for the constitution of national associations [14]. The constitution of the German Association of Surgery in 1872 
was within the German speaking countries - besides the constitution of the German society of ophthalmology in 1857 [15] - the important marker for gathering interested physicians specialized in surgery in all its dimensions. Internationally, urologists in 1886 founded the American Association of Genito Urinary Surgeons in the United States and the Association d' Urologie France 1890, the American Urological Association was established in 1902 [16].

In Germany, the first steps to establish a society only dedicated to urology were done in 1896 during the "Assembly of German naturalists and physicians" but it needs up to the time of the death of the difficult character of Max Nitze (1848-1906) for establishing a German Urological Association in 1906. The "German assembly of naturalists and physicians" in Stuttgart offered the concrete framework to start again a founding process among German speaking urologists to establish a urologic association. Research within the last years could only partly proof the narrative that the difficult character of $\mathrm{Max} \mathrm{Ni}^{-}$ tze [17] was the only problem within the constitutional process before [18].

The first meeting of the new established DGU was announced in Stuttgart in 1906 during a meeting of the "assembly of German naturalists and physicians" and was announced to be held in Vienna during the following year. This gave enough time for the information of physicians and surgeons who were truly in the new specialty. The first president of the DGU, Anton Ritter von Frisch (1849-1917), Vienna General Policlinic, constitutes within his presidential address the historical - critical method besides the scientific as equal for research within the new specialty, a fact that seems often to be forgotten today [19]. The same did famous Hugh Hampton Young (1870-1945) within the United States writing the foreword for the newly established Journal of Urology in 1917 [20]. ${ }^{1}$ Anton Ritter von Frisch started his presidential address with a differentiated historical introduction and derivation of the new subject urology and assigned the historical critical method as an integrative and constitutive part of the specialty from its set on. Especially in view of the fact that urology had to fight for its appreciation at universities and general hospitals up the 1970th in many countries, this approach has not

1“....a medium in which all types of papers upon the field of common interest may appear-archives of Urology-historical, embryological, anatomical, biochemical, pharmacological, pathological, bacteriological, surgical and medical, experimental and clinical..." Hugh Hampton Young J. Urol Vol 1 Foreword. lost popularity up to now but seems to be forgotten in parts of the community especially in relation to university education or publishing boards of some urological journals.

\section{The Setup of the Urological Museum of the DGU}

Concurrent within this process in medicine to become specialized at the end of the 19th century the idea consolidated to establish university collections often called "museum" or historic exhibitions during scientific meetings. This perceived educational need was a significant driver for the endurance and growth of medical collections [21]. The collections of scientific associations are a specific form of university collections. Otto Hildebrand (1858-1927), head of the department of surgery at Charité hospital looked upon collections as constitutional for universities and research [22]. In this way, the proposal of DGU member Alfred Hock of Prague fits into the image of the times. During the meeting of the DGU in 1909, he supported strongly the idea to establish an own collection and exhibition of books and instruments to teach the developments of urology in all its dimensions. This "museum of urology" with a broad spectrum of several independent collections together with art and cultural tools and objects should strengthen the identity of the specialty, which was board established in Germany in 1923. The specialty of urology should be represented as an important cross-disciplinary subject at all. First, the general assembly rejected the proposal. The idea to establish a collection and a museum based on an educational integrative aspect. We know from the files housed within the archives of the Nitze-Leiter collection in Vienna about history exhibitions during the meetings within the 1920th in Vienna.

\section{The Development of Museum, Library and Archives of the DGU}

In the 1950th Johannes Keller (1899-1970) from Dresden, Saxony, the new established archivist started a new project to establish a systematic collection within the history of urology, which disappeared during the establishment of the Iron Curtin in 1961. After Germany's reunification, some of his objects were found in Dresden in the cellar of the university department.

Furthermore, at that time the archivist of the DGU held a major lecture of $0.5 \mathrm{~h}$ during the meetings of the association, which had a 2 years rhythm. Since 1971, the 


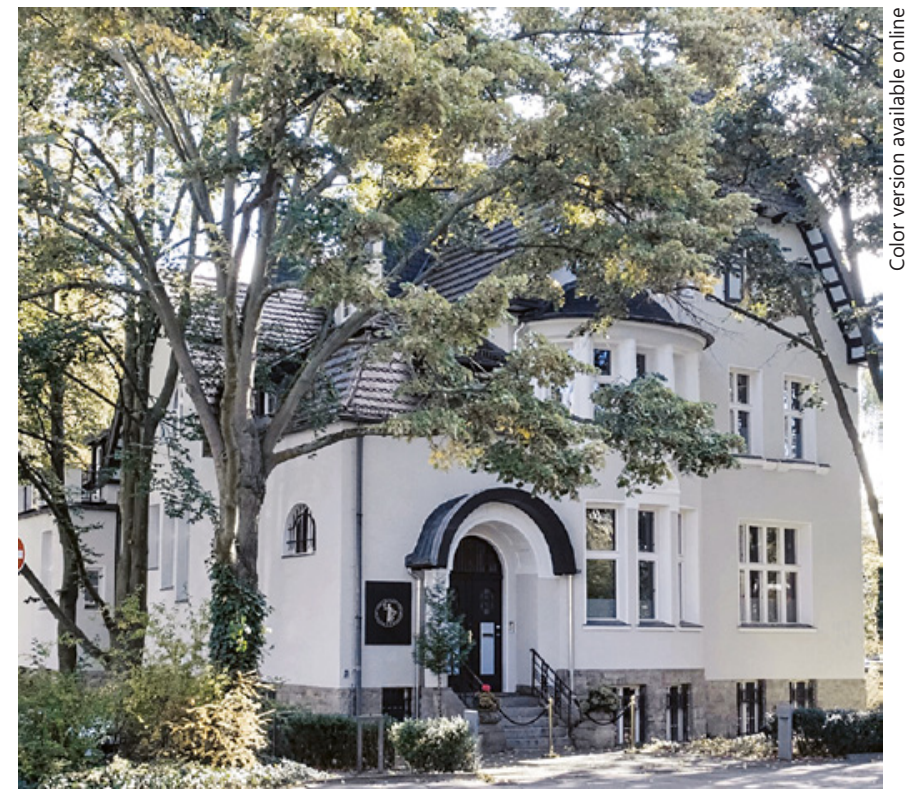

Fig. 1. The new "House of Urology" of the German Urological Association (DGU) at Martin-Buber - Str. 10, Berlin, which also accommodates the museum of the association. Repro Frei, with permission.

second archivist, Fritz Schultze - Seemann (1916-1987), started again to establish a collection in (West-) Berlin in collaboration with the institute of the history of medicine in Berlin at the FU. Up to 1987, he succeeded in collecting the older urologic journals. Furthermore, he established the base of the collection of endoscopes and cystoscopes.

The third archivist of the DGU, Peter Rathert, transferred the orphaned collection after the sudden death of Fritz Schultze-Seemann, which was actually endangered by flooding to Dueren (Rhineland), his working place, and started since the 1990th to build up a new institution. ("Archiv und Museum zur Geschichte der Urologie"). He succeeded to enlarge and expand the collection, which was now divided into the museum with a large collection of urological and medical artifacts, a substantial specialist library and an archive of personal papers and records related to the society and the development of urology in Germany. The collection was supported by major grants from urologist, by the industry and organizations. This laid the base for the concept, which is actual up to now. Further on special collections were established, for example, on dissertations omitt, early MD thesis dealing with urologic subjects, or textbooks of the 19th century.

In the year 2000, the collection with museum and library moved to Duesseldorf to the new house of urology at Uerdinger Strasse 64.

Urology on Display: Museum, Library and Archives of the DGU Duesseldorf-Berlin
In 2017, the permanent exhibition with the special exhibition moved to Berlin when the headquarter of the society became a new base here, first in a rented flat, since June 2019 in its own house of urology in Berlin-Zehlendorf, Martin-Buber-Strasse 10. So museum, library, and archives are not an unimportant attachment of the organization which has had derived from older times, but also this part of the institution is integrated in the daily work process of the association (Fig. 1).

Since 2008 in order professionalize the history aspects and culture of remembrance within the history-marketing concept of the association, the position of the archivist was split within the position archivist and the curator [23] who is very responsible for the museum. Since 2014 the position of a custos was newly established to support and advise the curator within the scenography and media tasks of the yearly exhibitions ( motto "the travelling museum") during the annual meeting and within the museum, the increased loans from other institutions, the more demanding restoration processes, the new registering process of all objects and the international exchange with other institutions and the broader research [24] and teaching tasks, which are quality indicators for the institution.

The institution is a member of the International Council of Museums and its German branch (DMB), the working group of German Medical Historical Museums, the European Association of Medical Historical Museums, and the European Academic Heritage Network and fosters a good collaboration with university institutions. For example, the Institute for the History, Theory and Ethics of Medicine, Heinrich-Heine-University, Duesseldorf (head Prof. Dr. Dr. h. c. Heiner Fangerau), the Didusch Center for Urologic History (Prof. Ron Rabinowitz, Prof. Mike Moran), the Nitze Leiter-Museum for Medical Endoscopy (Mag. Dr. Michaela Zykan, Doz. Dr. Manfred Skopec) Vienna, or the Collections of the EAU (Prof. Philip E. V. Van Kerrebroeck, Arnhem; Fig. 2)

\section{The Collections}

Today, the collection houses $>4,500$ books and brochures, 3,000 volumes of journals, and 600 dissertations and a countless number of archival documents, a partly digitalized portrayal collection and an exquisite collection of original lithographs. This will be added by around 1,500 urologic instruments, which present the specialty of

Urol Int 2020;104:2-9 5 


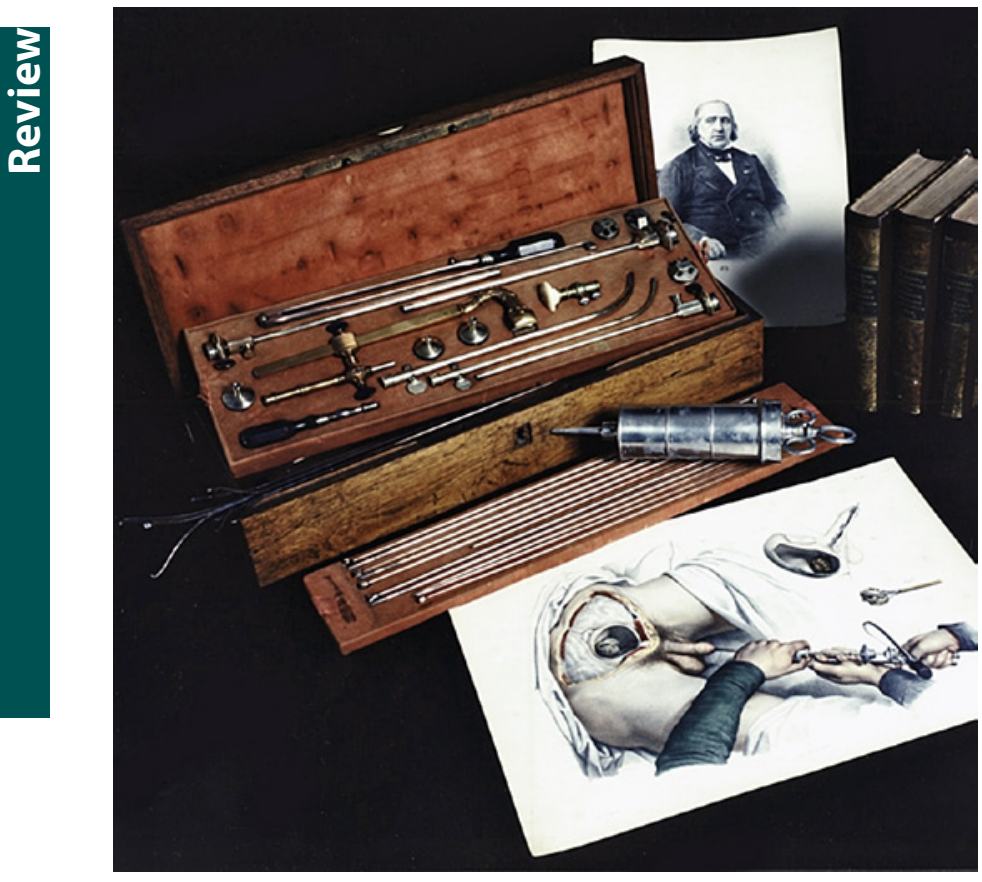

Fig. 2. The lithotripter invented by Civiale (1792-1867), which enabled for the first time within history of medicine to perform so called minimal invasive procedures. Civiale's publications were one of the first, which presents the new concept of scientific medicine by using statistics. Repro Moll-Keyn, with permission.

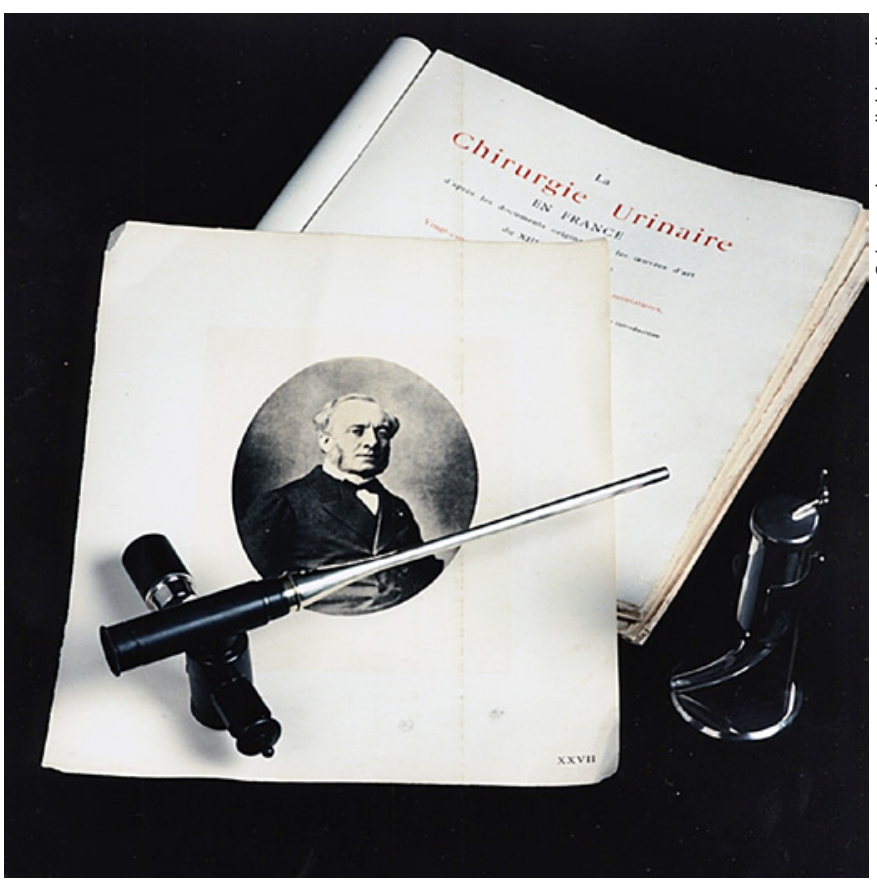

Fig. 3. Endoscope of Desormeaux (1815-1894), a milestone within the development of endoscopy before the advent of the Nitze cystoscope Repro Moll-Keyn, with permission. urology in general. This represents impressive the rich history of the multidisciplinary medical specialty in Germany on a daily base. Some curiosities, kitsch and personal belongings of urologists are telling our history and heritage.

Not only the light conductor of Desormeaux (1856) or a big lithotripsy set of Jean Civiale (1792-1864) made by Joseph-Frédéric-Benoit Charrière (1803-1876), are some highlights within the exhibition at Berlin. Diagnostic tools and instruments especially a rich collection of cystoscopes produced in Germany or abroad complemented the collection and exhibition. Thought as a universal museum the institution claims to collect the total spectrum of artifacts dealing with urology in all its dimensions. Within the permanent exhibition, the focus is laid on a radical selectivity due to space limitations and didactical purposes. Within the new exhibition, the museum highlights objects of the 20th century, which often were not considered far too little [25] (Fig. 3, 4).

\section{Involvement of the Topic History within the Society: Profile and Identity}

Museum, library, and archives of the DGU are the major and integral part of the history marketing process of the association $[26,27]$. Therefore, the institution "museum, library, and archives" is a direct subdivision of the Board of directors as the place to promote and organize the culture of remembrance of the medical association and demonstrates relevance to medicine and urology today. The Collections are the structure who represents the corporate identity of German speaking urology and is obliged to present the "corporate identity" of the DGU. Therefore, the institution is intensively connected with the process of communication of scientific knowledge of the medical association and is closely involved within. This addresses to the specific qualification of archivists, curators, and custodian people, which had to be professionals today, because they present values and concepts for the corporate identity in a special degree to the urologists and the public.

The collection assumed a heritage function: rather than displayed tools in current use, the collections preserve medical equipment deemed historically significant, often alongside libraries and archives. This expresses professional identity by forging in select artifacts. The museum as the main place for the collection of all historical material is the base and the place within 


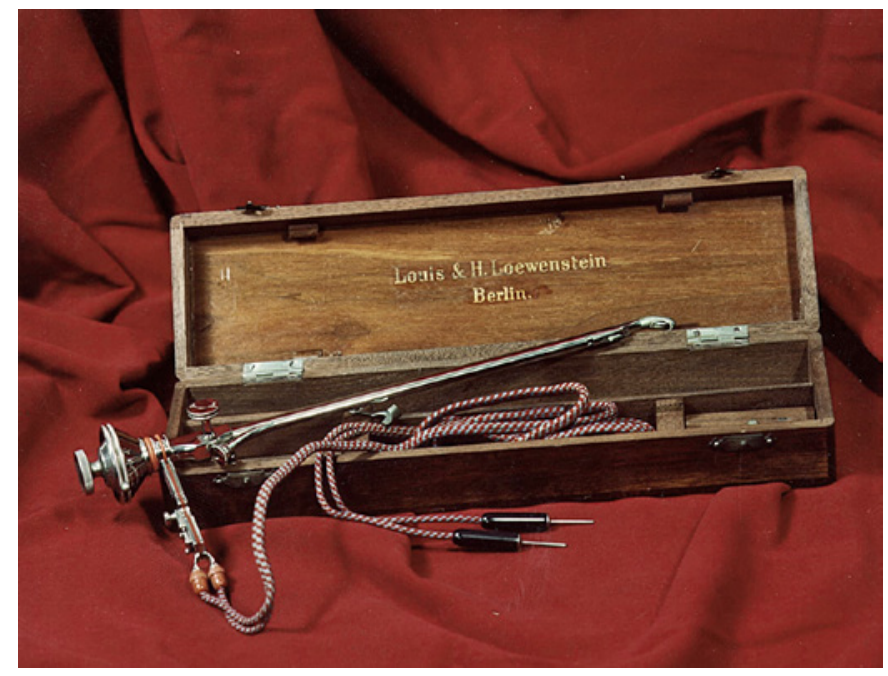

Fig. 4. Early Nitze cystoscope manufacturer: Louis \& H. Loewenstein, Berlin Repro Puggé, with permission.

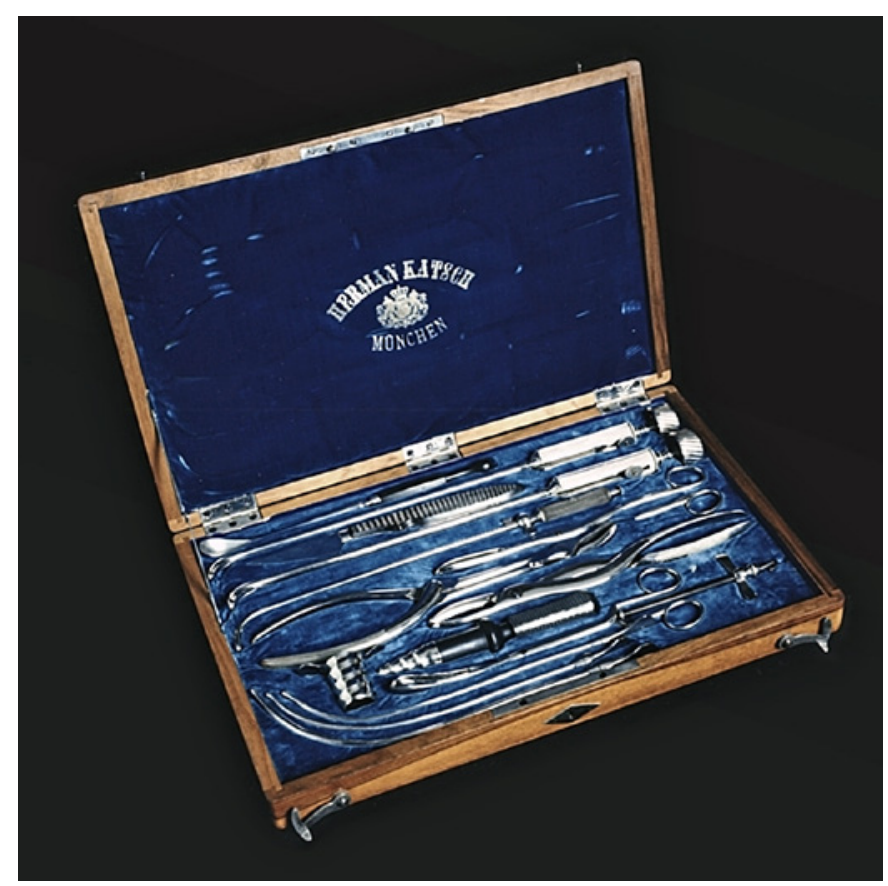

Fig. 5. Complete nonused lithotomy set presented to a Munich urologist at the beginning of the 20th century, manufacturer Katsch, Munich Repro Moll-Keyn, with permission.

the culture of remembrance within the association DGU and the specialty. Here urologists can celebrate their heritage. This approach within the culture of remembrance is the base of the museum and makes it understandable. This offers us on a research level the possi-

Urology on Display: Museum, Library and Archives of the DGU Duesseldorf-Berlin bilities to analyze the culture within urology, the medical association DGU, and the history of science. The institution is for urologists in general a "Memory $\mathrm{Mu}$ seum" at the intersection of museum, history landmark, and memorial place.

The objects and sources safeguard the interests of the DGU and urology at legal disputes in all dimension and could be considered as a medical expert opinion to describe current standards at a special point of the times (Fig. 5) [28].

\section{Aspects of the Museum: Aims and Visions}

The collections and museums of scientific associations, which were not connected directly with universities, are not allowed to legitimate only within their connected medical or scientific specialties. The utilization of the scientific collection as research infrastructure and educational institution is a major aspect of quality. The emphasis will be on generating innovative research together with medical historians and encouraging teaching with the use of the collections. The involvement of the museums staff in research networks links the museum to productive academic environments [29]. It is a major task of the curator and custos to increase the visibility and availability of the scientific collections not only for urologists but also for the general public and also to provide individual consulting services in collection-related areas to other international institutions in urology.

At the new established exhibition in Berlin, the objects are arranged to shed light on urology in all its dimensions, urological research, diagnosis, and treatment. The visitors should be provided with information and should practice questions to past and present [30].

\section{Teaching the Students}

Within the university system, the collection of the museum of the DGU is well integrated with an university seminar "OR meets museum" to enable students not only to handle instruments but also to teach them special aspects of the history of science in all its dimensions or within a seminar on medical terminology.

During the last decade, objects of museums dedicated to the history of medicine or scientific collections became a more important part within the teaching process of physicians in Europe. The use of real museum examples has 
not become an integral part in all institutions and universities in Germany [31]. Using new media students and their teachers removed themselves from objects with the consequences of abstract teaching at universities. Instruments became a so-called Black Box. Here museums objects can play a counterpart because they demonstrate the history of technique but also can show function more easily. The new teaching model in Germany within medicine allows more flexibility and new topics on teaching.

Since 2009, we use historic objects from our collections within several university settings. We used single objects and sources from our archives in different course formats at universities. With coworkers from the university we started to use this model, for example, during visiting lectureships at university summer schools to underline the topic presentation by special objects. The idea was that real objects could be handled directly could be watched, could be asked, could be described, and could be interpreted. Our main concern within the history of medicine is to present real objects and sources, to present techniques of object research to underline the step of visualization as a major point of perception. Practically students should learn to handle a cystoscope, which they otherwise will not learn in the German system. The evaluation of our courses showed a high rate of satisfaction [32].

\section{Teaching the Public}

During the last decade, museums have developed in institutions, which provide education within a multicultural and heterogeneous society in Germany and Europe. Within these institutions now, relevant historical and political discourses were reflected and underlined by relevant exhibitions. This led to a consolidation and melting of history, politics, and the culture of remembrance and often to flowing borderlines between museums and exhibitions. Museums and exhibitions have an important weight in adopting our past, but also to institutions, which gave orientation for presence and future in a rapidly developing society and also for private and collective inspiration of their visitors $[33,34]$.

For the heading "university triggered research" this meant, for example, for the NS project of the DGU, that our archives could provide the researchers in medical history with relevant sources, so that at the end of the protect a relevant exhibitions during the annual meeting of the DGU could focus the problematic time in a multidimensional way besides a 2 volume book edition, a monography, and an MD thesis. Another aspect of this project was that we could reflect the culture of remembrance within our society and the specialty of urology in Germany because several narratives existed during the last 40 years.

\section{References}

1 Burckhard D, Hohls R, Prinz C, editors. Universitätssammlungen in Deutschland - Untersuchungen zu Bestand und Geschichte. Geschichte im Netz: Praxis, Chancen, Visionen. Teilband II: Historische Fach- und Themenportale. Reihe Historisches Forum; 2007. S. 228-243.

2 Wolfschmidt G, editor. Enhancing University Heritage-Based Research. Nuncius Hamburgensis. Beiträge zur Geschichte der Naturwissenschaften. Volume 33. Hamburg: Tradition; pp. 17-29.

3 Alberti SJMM, Hallam E, editors. Medical Museums Past, Present, Future Royal College of Surgeons, London.

4 Rehberg KS. Refuge for Materiality in a virtualised World in: Museen zwischen Qualitiät und Relevanz Denkschrift zur Lage der Museen/ Museum: Between Quality and Relevance Denkschrift on the State of Museums Berliner Schriftenreihe zur Museumsforschung Vol 30 Deutscher Museumsbund Holy Verlag, Reiter Druck Berlin; 2016. p 19-20 esp p. 20.

5 Moll F, Moll-Keyn J. The Museum of the German Urological Association Presentation
Objectives and Artefacts History Booth Talks. \# 3608 Annual meeting of the AUA, Chicago 4th May 2019.

6 Engel RM. The William P. Didusch Museum of the American Urological Association. J Urol. 1998 Dec;160(6 Pt 2):2450-1.

7 Engel RM. Das „William P. Didusch Center for Urologic History der American Urological Association" Neue, spannende Ansätze zur Urologiegeschichte in den USA - ein persönlicher Rundgang. Urologe. 2011;50:483-88.

8 Van Kerrebroeck P. The Permanent History of Urology Collection of the European Association of Urology (EAU) Presentation History Booth Talks \# 3608. Annual meeting of the AUA, Chicago 4th May 2019.

9 Habrich C. Zur Bedeutung von Sammlungen und Museen für die Wissenschafts- und Medizingeschichte. In: Vorstand der Deutschen Gesellschaft für Geschichte der Medizin, Naturwissenschaft und Technik (Hrsg) Ideologie der Objekte - Objekte der Ideologie Naturwissenschaft, Medizin und Technik in Museen des 20. Jahrhunderts. Schriften zur Naturwissenschafts- und Technikgeschichte; 1991. Bd. 4, Kassel, S. 15-30.
10 Halling T, Moll F. Fachkulturelles Gedächtnis und Erinnerungsorte in den medizinischen Wissenschaften. Urologe. 2016;55:122332.

11 Weber C. Universitätssammlungen [2012 (Recherche 8.5.2019)]. Available from: http:// ieg-ego.eu/de/threads/crossroads/wissensraeume/cornelia-weber-universitaetssammlungen.

12 Häner F. Dinge sammeln, Wissen schaffen. Die Geschichte der naturhistorischen Sammlung in Basel 1735-1850. Transkript, Bielefeld; 2017. p. 9-35.

13 Wissenschaftsrat. Empfehlungen zu wissenschaftlichen Sammlungen als Forschungsinfrastrukturen [2011 (Research May 8, 2019)]. Available from: https://www.wissenschaftsrat.de/download/archiv/10464-11.pdf.

14 Jardin A, Moll F. A Short History of the SIU with some emphasis on the early years of the AIU and the initial meetings of 1907-1914. In: Schultheiss D, Zykan M, editors. SIU meets Berlin: Urology a Century ago. International Nitze-Leiter Research Society of Endoscopy. Vienna: Neue Medien, Bad Vöslau; 2011. pp. 20-41. 
15 Esser A. Geschichte der Deutschen Ophthalmologischen Gesellschaft. Zur ersten Säkularfeier im Auftrage der Gesellschaft geschrieben von Albert Esser. München: JF Bergmann; 1957. https://doi.org/10.1007/978-3-64286847-4.

16 Engel R. Entwicklung der Urologie in den USA. In: Konert J, Dietrich H (Hrsg) Illustrierte Geschichte der Urologie. Springer, Heidelberg, Berlin: New York; 2004. p 229-85.

17 Valentine FC. Obituary Max Nitze American. J Urol. 1906;2:291-2.

18 Moll FH. Zum 70. Kongress der Deutschen Gesellschaft für Urologie e. V.: Beispiele zu Netzwerken und Denkkollektiven bei ihrer Gründung 1906/1907 und weiteren Entwicklung. Urologe A. 2018 Sep;57(9):1111-32.

19 Von Frisch. Historischer Rückblick für die Entwicklung der Urologischen Diagnostik Wiener Med. Volume 20. Wschr; 1907.

20 Young HH. Foreword. J Urol. 1917;1(1):2.

21 Hallam E, Alberti Samuel JJ. Bodies in Museums. In: Alberti SJMM, Hallam E, editors. Medical Museums Past, Present. London Future Royal College of Surgeons; 2013. p. 1-15.

22 Werner, N. Zahnärztliche Moulagen und anatomische Wachsmodelle aus den Sammlungen des Zahnärztlichen Instituts der
Berliner Universität (1884-1945). Diss Med. Berlin; 2015. p 52.

23 Söderqvist T. The Participatory Museum and Distributed Curatorial Expertise. NTM. 2010; 18:69-78.

24 Arnold K, Söderqvist T. Medical instruments in museums: immediate impressions and historical meanings. Isis. $2011 \mathrm{Dec} ; 102(4): 718-29$.

25 Moll F, Rathert P. Urologie im Museum: 10 Jahre in Düsseldorf Lebendige Medizingeschichte im Museum und Archiv für Urologie der DGU. Urologe. 2010;49:957-962.

26 Moll FH, Halling T, Rathert P, Fangerau H. Geschichte in der öffentlichen Kommunikation wissenschaftlicher Fachgesellschaften : "History marketing". Urologe A. 2014 Oct; 53(10): 1525-32.

27 Schug A. History marketing: Ein Leitfaden zum Umgang mit Geschichte im Unternehmen. Bielefeld: Transcript; 2003.

28 Moll, F. Das Steinschnittbesteck des Königlich Bayrischen Sanitätsrats Dr. C. Schneider. München, 1912. Urologe [B]. 2002;42: 520-523.

29 Prüll CR. Medizin im Museum, aber wie? Bemerkungen zur Frage der Museumskonzeption am Beispiel des Medizinhistorischen Museums der Universität Zürich Medizin im Museum. In: Schulz S, Müller I (Hrsg) Jahrb, editors. der Medizinhist Sammlung der Ruhr Universität Bochum: Klartext, Essen; 1995. p. 2-19, 29.

30 Schnalke T. Tracing life The Berlin Museum of Medical History at the Charité. In: Alberti SJMM, Hallam E, editors. Medical Museums Past, Present, Future. Royal College of Surgeons: London; 2013. p. 130-143, 142.

31 Schnalke T. Changing Places Das medizinhistorische Museum als Schausammlung, Lehrkabinett und Forschungsstätte (2011). Available from: https://edoc.hu-berlin.de/bitstream/ handle/18452/1985/schnalke.pdf?sequence $=1$ reserach 08.05.2019.

32 Moll F. Objekte haben Konjunktur Zum Wert von Sammlungen wissenschaftlicher Fachgesellschaften für die moderne Lehre in der Urologie. Urologe. 2015;54:261-265.

33 Moll F, Rathert P, Skopec M, Engel RM, Fangerau H. Neue Formen der Wissenskommunikation medizinischer Fachgesellschaften: Gedanken zu wissenschaftlichen Sammlungen und Museen für Urologie. Urologe. 2011;50: 210-216.

34 De Haan P. A public-oriented and educational museum. In: von Kelly M, editor. Managing university museums: education and skill. Paris: Organisation for Economic Co-operation and Development; 2001. pp. 121-31. 